\title{
Drivers toward Social Entrepreneurs Engagement in Poland: An Institutional Approach
}

\author{
Agnieszka Pacut $\mathbb{1}$ \\ Departament of Management of Public Organisations, Cracow University of Economics, 31-510 Krakow, Poland; \\ agnieszka.pacut@uek.krakow.pl
}

Received: 16 December 2019; Accepted: 15 January 2020; Published: 21 January 2020

\begin{abstract}
The aim of this study is to identify the factors that influence the involvement of individuals in social entrepreneurship in Poland from an institutional economics perspective. The research is based on exploratory data analysis using qualitative data covering 22 interviews with social entrepreneurs and 10 representatives of stakeholders from Poland as well as observations and secondary data. By employing an inductive approach and a case study methodology, it can be stated that involvement of social entrepreneurs is stimulated by a complex set of factors. Moreover, the results show the importance of the institutional environment for social enterprises in Poland, including the impact of formal and informal institutions on their development. The findings contribute to enhancing the knowledge on factors determining the establishment and development of social enterprises in Poland given the institutional economics perspective.
\end{abstract}

Keywords: social enterprise; social entrepreneurship; social entrepreneur; factors; institutional environment; Poland

\section{Introduction}

Social entrepreneurship is a relatively young, knowledge-intensive area and a social practice of interest to researchers since the late 20th century (Brock and Kim 2011; Nicholls 2006; Short et al. 2009; Granados et al. 2011; Gras et al. 2014). It comprises a variety of activities and processes that lead to the creation and consolidation of social value by individuals, groups of citizens, and organisations. The entrepreneurial activities undertaken for social and/or public benefits, oriented towards change and/or innovation, apply market-based solutions, and remain under the influence of their external environment (Brouard and Larivet 2010). Researchers of social entrepreneurship are primarily interested in the following four topical areas (Ferri 2014; Urbano et al. 2017): (1) defining social entrepreneurship, (2) comparing social enterprises with other organisational forms (non-profit and commercial enterprises), (3) examining the entrepreneurial process in consideration of the emerging opportunities and social impact assessment, and (4) factors that determine the development of social enterprises.

The considerations presented in this article address the fourth research area and reflect the author's interest in the various factors that may have an impact on the emergence of social enterprises. The literature review reveals the multiple and complex conditions which influence the creation and growth of entities whose activities combine social and economic objectives. Thus, social enterprise results from the interaction between social entrepreneurs and the environment in which their activity is embedded (Mair and Martí 2006; Austin et al. 2006). This kind of interaction is one of the triggers as well as a factor which contributes to the development of social enterprises (Leadbeater 1997; Mair and Martí 2006; Perrini and Vurro 2006; Perrini et al. 2010; Urbano et al. 2010). Moreover, the importance of the context (environment) in which these activities are rooted should be emphasised (Mair and Martí 2006; Kerlin 2017). Despite certain advances, this area requires further research, especially in terms of the institutional models that affect the activities of social enterprises (Kerlin 2017). 
Given the emergence of a number of models of social enterprises worldwide, the impact of the external environment on the decisions and behaviours of individuals is crucial. Research findings demonstrate that the configurations of institutional factors at meso and micro levels may reflect a decisive impact on particular domestic models of social enterprises (e.g., Kerlin 2017; Stephan et al. 2015). On this basis, it can be stated that the knowledge of models shaping the development of social enterprises operating in Central and Eastern Europe, including Poland, remains limited (Kerlin 2012, 2017).

Poland may provide an interesting example for the analysis of the development of social enterprises. It has a rich experience in cooperative and reciprocal activities, as well as centuries-old traditions of charity work (Pacut 2018a). Poland's integration with the European Union significantly boosted the debate on social enterprises' relevance to solving social problems. It also made it possible to test social enterprise solutions owing to significant public funding allocated to this purpose and public policy. On the one hand, for more than 15 years, social economy development programmes have been created at national, regional, and local levels, and relevant legislation was adopted (e.g., the Social Cooperatives Act). These activities are accompanied by transfers of substantial public funds for the creation of new organisations which combine social with business objectives (e.g., social cooperatives, non-profit companies), support the process of economising activities by non-governmental organisations, and disseminate this form of activity among various target groups in Poland (Ministry of Labor and Social Policy 2014). On the other hand, potential aid recipients are neither particularly interested in setting up social enterprises nor aware of their performance. The literature lists numerous barriers and limitations to the development of social enterprises, such as the lack of more effective mechanisms for stimulating their creation and development, difficulties in accessing external sources of funding, the lack of appropriate legal forms, inadequate specialist business support, and poor understanding of the concept of entrepreneurship with a social objective (European Commission 2015, 2016; Stronkowski et al. 2013). The factors and conditions of engagement in social enterprises are poorly recognised by both researchers and public decision-makers, especially in their institutional aspect.

The aim of the study is to identify and analyse factors influencing the involvement of individuals in social entrepreneurship in Poland from an institutional economics perspective. The empirical research was intended to answer the following questions: (1) What factors influence the involvement of individuals in social enterprises? and (2) How does the institutional environment affect the engagement in social entrepreneurship in Poland? The theoretical framework for the research and analysis of findings was provided by new institutional economics, which defines and explains the importance of the institutional environment for social phenomena (North 1991, 2005, 2017; Furubotn and Richter 2005). The findings draw on a collective case study informed by a variety of data sources, including individual in-depth interviews conducted among 22 social entrepreneurs and 10 stakeholders, observations, and secondary data. Empirical research enabled the identification of reasons for the establishment of social enterprises. Moreover, the results show that involvement in this kind of activity results from multiple factors influenced by formal and informal institutions as well as the methods of their enforcement.

This article consists of five sections. Beside the Introduction, Section 2 contains an overview of the concept of social enterprises, discusses the factors that contribute to their development, and outlines the theoretical framework of the analysis. Section 3 presents the strategy of empirical research based on qualitative analysis. Section 4 focuses on the results and provides the discussion of the findings. Final considerations contained in Section 5 are devoted to a summary of the conclusions followed by the research limitations and further research directions. 


\section{Literature Review}

\subsection{Social Entrepreneurship Field}

Social entrepreneurship has been defined by researchers from diverse perspective. It is described as a multidimensional construct (Sullivan Mort et al. 2003), a complex and multifaceted phenomenon (Mair and Martí 2004), as well as a multi-perspective phenomenon (Perrini 2006). The multidimensionality and complexity of social entrepreneurship are reflected in different approaches present in the literature. The literature distinguishes between objective, subjective, and processual approaches (Mair and Martí 2004; Brouard and Larivet 2010; Dacin et al. 2010; Bacq and Janssen 2011). The objective approach emphasises organisation, called a social entrepreneurship organisation or a social enterprise. It has a dual nature, which reflects both the implementation of social objectives and the market orientation. Social enterprises may take diverse legal forms. They combine managerial efficiency with addressing social needs and reinvesting profits for the benefit of the community (Haugh 2006). The subjective definition of social entrepreneurship focuses on the social entrepreneur perceived as a visionary individual who acts as a change agent in the social sector, seeking to effect systemic changes and sustainable improvements (Dees 2001). Finally, the processual approach includes the description of activities, stages, and processes undertaken in order to create and consolidate social value. In this case, the analyses involve, among others, the process leading to the identification of a specific social problem and its solution as well as to conducting of social impact assessment and the business model applied (Robinson 2006). From this perspective, social entrepreneurship is also analysed as a process of identifying, discovering, and taking advantage of entrepreneurial opportunities (Brooks 2009). This multidimensional term is also associated with a broader approach to innovation, where the emergence of new ideas is treated as a collective problem in the context of meeting social needs (Kopyciński 2018).

The literature also reflects both narrow and broad approach of social entrepreneurship (Perrini 2006). In the former case, the phenomenon is described as a way of aligning the activity of a non-profit organisations towards a more market-oriented, independent (from the public sector), customer-oriented, and self-sustaining model. The second approach recognises social entrepreneurship as a new and independent, extremely interdisciplinary field of research. In line with this, the organisational form (belonging in the for-profit, non-profit, or public sectors) is disregarded, with priority granted to innovative ideas and market-based activities.

The lack of agreement on the essence of social entrepreneurship creates extreme opinions about it. Some scholars argued the field to be in its pre-paradigmatic stage (Nicholls 2010). It is characterized by a debate on legitimate methods and research problems, the utility of this concept, and the quality of solutions relevant to the new field of knowledge. Due to the above, the analysis of social entrepreneurship is associated with various problems and inaccuracies of epistemological and methodical nature (Nicholls 2010). Other researchers demonstrate a progressive process of institutionalization of social entrepreneurship. This is reflected in the scientific journals and monographs on social entrepreneurship and in the establishment of centres, academic units, and scientific networks specializing in promoting practical knowledge about social enterprises (Sassmannshausen and Volkmann 2016). The latest results of bibliometric research conducted by Hota et al. (2019) show that the social entrepreneurship concept was developed by the inclusion of different organisational aspects (e.g., mission and vision, resources, legitimacy). The authors have identified nine thematic areas (clusters) in period from 1996 to 2017. In turn, Romani-Dias et al. (2018) described 'academic production on social enterprises studies' using the following six categories: (1) understanding social entrepreneurship; (2) governance and relationships with stakeholders; (3) attempts to increase practical references and samples within the field; (4) organizational learning, structure, and critical factors for success and failure of social entrepreneurship; (5) metrics, indicators, and social impact generated by social entrepreneurship; and (6) legislation of different countries and how it relates to social entrepreneurship. 
Given the aim of this article, social entrepreneurship can be considered as an umbrella term for the functioning of individuals, organisations, or initiatives running a business for social purposes (Seelos and Mair 2004). Social enterprises are described as organisations that engage in business activities in order to achieve social objectives. They may take various legal forms, but what they have in common is the principle of using market solutions to achieve social objectives (Haugh 2005, 2006). Its organisational dimension comprises all types of enterprises which seek financial, social, and environmental outcomes (Germak and Robinson 2014). The social entrepreneur can be defined as "the individual that conceives of the initial idea, moves toward launching the venture, and works to sustain the venture" (Germak and Robinson 2014, p. 7).

\subsection{Factors Influencing the Involvement in Social Enterprises}

The growing global interest in social enterprises can be justified by the economic, social and political changes which have taken place in recent decades. In particular, increasing social inequality, accumulating environmental problems, decreasing availability of public funds, and concentration on market mechanisms in the distribution and redistribution of resources can be indicated here. Furthermore, the growing importance of corporate social responsibility and proactive reactions of representatives of the commercial sector to complex social problems is emphasised (Hoogendoorn et al. 2010). The origin and development of social enterprises is also analysed in terms of the role of demand factors (demand for social services produced by social enterprises), supply factors (activity of social entrepreneurs), and their contextual and institutional determinants (Chell et al. 2010).

Therefore, social enterprise as a process of creating social added value depends on several factors. For example, the literature emphasises the role of opportunity, human, and capital resources with regard to the environment (Austin et al. 2006). Lumpkin et al. (2013) explored such factors as motivation/mission, identification of opportunities, access to capital and diversity of stakeholders as unique characteristics of social enterprises. For Kickul and Lyons (2012), the creation of social enterprises results from individual motivations of social entrepreneurs, social needs to be addressed, and from the capacity of the community (and society at large) to meet these needs. It should be added that mission accomplishment tends to be associated with the pursuit of opportunities and appropriate deployment of human and other resources. The model proposed by Kickul and Lyons (2012) assumes that the above-mentioned factors relate to each other, while all the activities associated with this process occur in a specific context created by politics, culture, economy, social norms, geography, history, and the legal and money systems. This context penetrates and affects social enterprises initiatives. According to Sekliuckiene and Kisielius (2015), individual, organisational, and contextual factors (legal, environmental, etc.) constitute important variables which may support or impede such initiatives.

The researchers confirm the importance of the environment (context, eco-system) for social enterprises (Austin et al. 2006; Perrini and Vurro 2006; Hoogendoorn and Hartog 2011; Kickul and Lyons 2012; Sekliuckiene and Kisielius 2015). All activities in this area take place in a specific environment which affects the shaping of social enterprises-from the initial stages to the creating outcomes (Teo and Tan 2013; Lumpkin et al. 2013; Sekliuckiene and Kisielius 2015). On the one hand, social enterprise is stimulated by the needs of the environment, and on the other hand, it can be limited (Weerawardena and Mort 2006). The bibliometric analysis conducted by Hota et al. (2019) points to the study of the institutional environment as one of nine separate clusters of research on social entrepreneurship. This research described how the institutional context affect the conduct of social enterprises. It concerns two issues: the interaction between social entrepreneurship and its environment (environmental dynamics) and support structures (Hoogendoorn et al. 2010). For instance, Stephan et al. (2015) explained the importance of institutional support and institutional void for engagement in social entrepreneurship. The institutional factors demonstrated in this research model included values and norms (informal institutions) and government activism, treating the latter as an important formal institution shaping demand for social entrepreneurship. The results 
of the research have shown that the national context "drives" individual engagement in the social economy through a mechanism based on resources and the influence of motivation, and less through demand-driven incentives. Urbano et al. (2010) analysed the impact of the following selected factors: social values, entrepreneurial and social attitudes, and social networks (informal institutions) and state financial support (formal institutions) on the emergence and implementation of social enterprises in Catalonia. Their research showed that informal institutions are more important in this respect. They influence not only the emergence but also the implementation of such activities in the country. Sahasranamam and Nandakumar (2020) investigated role of a country's formal institutions (financial, educational, political) on the relationship between individual capital (financial, human, social capital) and social entrepreneurship entry. This study showed the nature of contingent effects of formal institutions on the relationship between individual capital and the emergence of social enterprises.

\subsection{Theoretical Framework}

The theoretical framework of social enterprise was provided by new institutional economics, which defines the institutional environment as an area governed by various rules regarding the behaviour of individuals and organisations in social interactions (Davis and North 1971; Furubotn and Richter 2005). That means that various social, cultural, and political norms (institutions) determine the way social actors act (North 2005, 2017).

According to the typology proposed by North, a prominent representative of new institutional economics, two kinds of institutions influence social enterprise, i.e., formal (rules, laws, constitutions) and informal institutions (norms of behaviour, conventions, self-imposed codes of conduct) (North 1994, p. 360). Formal institutions are established by law. Their observance is based on formal control, but also depends on informal institutions. Informal institutions can be defined as socially rules, usually unwritten, evolutionary, transmitted, and enforced outside (Helmke and Levitsky 2004). Referring to the North's achievements, the importance of beliefs and mental models in shaping the actions and choices made by individuals can be emphasised. Mental models are "internal representations that individual cognitive systems create to interpret the environment," whereas "the institutions are the external (to the mind) mechanisms individuals create to structure and order the environment" (North 1994, p. 4). By defining of institutions, North points to the methods of their implementation and enforcement. "Together they define the incentive structure of societies and specifically economies" (North 1994, p. 360).

The methodological postulate of the importance of institutions is common to different approaches occurring in institutional economics, both classical and new. Institutions, as rules of the game (North 2017), determine the decisions made by social actors. However, the question is not whether institutions matter, but what role they currently play (Aidis et al. 2007). In line with those considerations it can be stated that involvement of social entrepreneurs should be analysed in terms of the interactions between institutional environment consisting of formal and informal institutions and social enterprises (Figure 1).

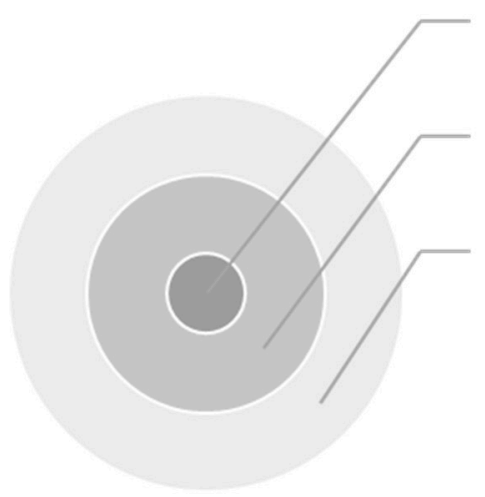

social entrepreneur

social enterprise

Institutional environment

(formal, informal institutions and the methods

of their implementation and enforcement)

Figure 1. Institutional framework of social enterprise. Source: Own study. 
Based on the theoretical background, this article attempts to explore the experience of Poland in implementing of social entrepreneurship. In line with this, the following two research questions were specified: (1) What factors influence the involvement of individuals in social enterprises? and (2) How does the institutional environment affect the engagement in social entrepreneurship in Poland?

\section{Material and Methods}

\subsection{Research Methods and Techniques}

The empirical study is based on qualitative methods. The choice of methodology is justified by the research objective and questions. Qualitative research relies on the description of the observed phenomena in their natural environment and an attempt to explain them applying the terms used by the studied individuals (Denzin and Linclon 2009). Due to their advantages, such as flexibility of the research process, depth of communication, and the opportunity to take a holistic approach to the problem at hand, qualitative methods are appropriate for the study of the entrepreneurship phenomenon and are often used in research on social enterprises (Short et al. 2009). Quantitative research is not applied here because it is insufficient when the research aims to understand the nature of the phenomenon, its context, and interactions with other elements (Patton 2015). Qualitative methods allow for a thorough understanding of entrepreneurial activities and their context (cultural, social, etc.) as well as their relationships with the immediate environment. Therefore, it can be concluded that the potential benefits of using the qualitative methods outweigh their limitations, which include, among others the lack of intersubjective verifiability of the obtained data (a positivistic understanding of knowledge), differences in the structure and interpretation of the collected material by different researchers, difficulty in maintaining optimal openness, and objectivity toward the researched person (Dembińska 2012).

For the research analysis, the collective case study (Stake 2009) was applied. The collective case study enables researchers to understand the phenomenon of interest not as a single case but the context of similar cases. As Stake (2009) emphasises, this is not a classical case study, but an instrumental case study extended over several cases, which involves studying a number of them in order to obtain an adequate insight into the general phenomenon. The cases were analysed in an objectified manner as a basis for making comparisons in order to identify the regularities governing the social phenomenon. The reason for choosing this method was not only the poor knowledge of the research problem in Poland, but also the multi-faceted nature of social enterprise, its dynamic development, and the need to explore the context and circumstances in which individuals engage in entrepreneurial activity (Yin 2009, 2015). The analysis based on the collective case study method served to create or complement the existing theories of social entrepreneurship. The theory-generating goal implies the possibility of developing a new theory or modifying, advancing, refining or identifying new elements of existing theories by analysing the phenomenon at hand (Yin 2009). Despite the existing knowledge on the determinants of establishment and development of social enterprises, the institutional impact on social enterprises remains modest. Case studies contribute to an in-depth examination of phenomena and processes in their actual context and thereby offer invaluable insights into the empirical reality (Patton 2015). Using a case study methodology and based on an inductive analysis of empirical data, the existing knowledge on the involvement motives of social entrepreneurs can be expanded.

In order to ensure the credibility of the findings, the data triangulation as well as researcher triangulation (in the final stage of the research, studied participants were enlisted to review and verify the conclusions) was applied (Denzin 1978). The following data collection techniques were used:

- Individual in-depth interviews conducted among 32 interviewees (including 22 social entrepreneurs (founding member) and 10 stakeholders-representatives of the immediate environment, i.e., public administration, social economy support centres, loan and guarantee organisations);

- On-site observations conducted in social enterprises;

- Analysis of documents and materials concerning the interviewed social enterprises. 
The in-depth interviews were conducted in 2017-2018, each lasting on average about 1.5 hours. Interviews were recorded with the consent of respondents and then fully transcribed. The transcription results were anonymised, and most of them were published in the Harvard Dataverse database (Pacut 2018b).

\subsection{Sample Selection}

The selection of representatives of social enterprises to be interviewed as part of the collective case study was based on the principle of theoretical replication. The assumption was made that enterprises that obtain extreme results should be purposefully selected (Yin 2015). In other words, it was assumed that maximum-variation case sampling (Eriksson and Kovalainen 2008) enables an analysis of social enterprises operating in different contexts, which remain under the influence of different factors. The selection of extreme cases for analysis was primarily aimed at ensuring the heterogeneity of the research sample.

The research was conducted based on social enterprises in Poland. Owing to the lack of a legal definition of social enterprise in Poland and the lack of consensus among national researchers and decision-makers on the criteria for selecting this group of entities, EMES criteria (The Emergence of Social Enterprises in Europe) were used for empirical research. Accordingly, organisations which qualified as social enterprises were autonomous entities, continuously engaged in business activity, which employed regular staff and had a clearly stated objective of serving the community. In line with this, they were characterized by limits in the profits distribution, participatory nature (i.e., the involvement of people supported by the organization), and a democratic management style (Defourny 2001). These criteria were operationalized using the findings of Polish researchers (Herbst 2008; Małecka-Łyszczek 2017). These criteria were met by the following organisations operating in Poland: foundations and associations conducting economic activity, non-profit companies, social cooperatives, and labour cooperatives. This classification of social enterprises was also adopted at the central level in National Social Economy Development Program in Poland (Ministry of Labor and Social Policy 2014).

Social enterprises were selected on the basis of desk research from an independently compiled database, which comprised a list of over 100 organisations operating in Poland, from among the winners of national and regional competitions for the best social enterprises, certified social enterprises, as well as other good practices identified on the basis of a review of reports, studies, monographs, etc. In total, 13 entities were invited to participate in the research. Additionally, a group of 9 enterprises in liquidation, bankruptcy or those with serious problems, which hampered their further activity, was selected by stakeholders participating in the research and by snowball sampling method. Appendix A presents the profile of the selected 22 social enterprises.

Moreover, 10 different stakeholders were also selected for interviews. They represented organisations including, public administration, social economy support centres, and loan and guarantee organisations. These interviewees were directly involved in the cooperation with and support of social enterprises, performing executive, managerial, or line functions (e.g., head of the commune, head of social economy department in a municipal office). The stakeholder interviews covered the experiences of stakeholders in supporting social enterprises. Appendix B presents a detailed profile of 10 representatives of the immediate environment of social enterprises.

\subsection{Data Analysis Methods}

The data analysis involved selection and classification followed by a general review in order to capture the significance of the collected information. After that, the data were categorised using theory-based coding and supplemented by data-based coding (Creswell 2013). The procedure was carried out manually using Word, Excel. In the next step, the codes were specified and selected in order to reduce the data. This contributed to identify several categories of institutional factors affecting the process of social entrepreneurship, which were analysed on an individual basis by using the identified criteria (i.e., 'good practices' versus entities in the closing stages of their activity or those 
facing problems). In order to aggregate the findings from a series of single studies, the cross-case synthesis, as one of the techniques applicable to case studies, for data analysis was used (Yin 2009). For the research objective, an empirical approach on conducting a collective case study in order to develop theoretical propositions was designed. The interviews were analysed using the content analysis technique. The results were illustrated by respondent's statements (anonymised, uncorrected for research purposes).

The validity and reliability of the findings were ensured by the following procedures of the research process: (1) Triangulation understood as the extraction of data from several independent sources (Yin 2009). Data for the analysis were collected by interviews (conducted in two groups of social entrepreneurs and stakeholders), observations made in social enterprises, the secondary materials and documents obtained; (2) Developing a research protocol, making it available to the respondents and taking into account the findings from further discussions; (3) Making public the qualitative data (interview transcripts) in the Harvard Dataverse database (Pacut 2018b). Table 1 summarises the research design for empirical research and the criteria to ensure the research quality.

Table 1. Research design of the empirical research.

\begin{tabular}{|c|c|c|c|c|}
\hline Research Subject & \multicolumn{4}{|c|}{ Social Enterprise } \\
\hline Research strategy & \multicolumn{4}{|c|}{ Case study } \\
\hline Data collection methods & \multicolumn{2}{|c|}{ In-depth interviews } & Observation & Secondary data \\
\hline Data sources & Social entrepreneurs & Stakeholders & Social enterprises & Social enterprises \\
\hline Quality assurance criteria & Resea & $\begin{array}{r}\text { Trian } \\
\text { Et } \\
\text { Comm } \\
\text { cher's self-awa } \\
\text { Validatior }\end{array}$ & $\begin{array}{l}\text { lation } \\
\text { cal } \\
\text { nicative } \\
\text { ness and developm } \\
\text { of findings }\end{array}$ & \\
\hline
\end{tabular}

The quality assurance applied in this research include the following criteria (Creswell 2013; Dembińska 2012; Flick 2011):

- The triangulation criterion: the use of more than one data source on a given topic.

- The ethical criterion: data protection and care for the well-being of respondents, respect for their views, sensitivity to their situation.

- The communicative criterion: the research process requires dialogue with the individuals, getting to know their lifestyles and behaviours.

- The researcher's self-awareness and development: ensuring a high level of one's own awareness and knowledge (keeping a research journal, consulting on current issues with experienced researchers specialising in qualitative research).

- Validation of findings.

The author is aware of certain weaknesses and disadvantages associated with the use of qualitative methods, including the limitations of the case study method; hence, the main attention was paid to the quality of research (Flick 2011).

\section{Empirical Findings and Discussion}

The results of empirical research are presented and discussed based on the main research questions: (1) What factors influence the involvement of individuals in social enterprises? and (2) How does the institutional environment affect the engagement in social entrepreneurship in Poland? 


\title{
4.1. Factors Affecting the Involvement in Social Enterprises
}

Based on the interview data, observations, and secondary sources, the research analysis showed a variety of factors for individual decisions to involve in social enterprises. As a result of the cross-sectional analysis of the examined cases, seven main factors determining the decisions of individuals to involve in social enterprises were identified: social or personal advantages, public support, random events, norms and values, self-fulfilment, social and family models, and beliefs and ideas. Selected contributions from respondents indicating these factors, based on in-depth interviews, are presented in Table 2. The cited statements of individual respondents participating in the study were anonymised and translated literally. Each quote is followed by a code (e.g., Se1, S1), which indicates respondent type (Se-social enterprise, S—-stakeholder representative), whereas the digits represent the ordinal number of the respondent (interviewee). The identified factors include a wide range of motives for involvement in social enterprises and can be specified as follows.

Table 2. Involvement in social enterprises in opinion of social entrepreneurs—selected respondent statement based in individual in-depth interviews.

\section{Social and personal advantages}

\begin{abstract}
“We would like to achieve a better, people-oriented tourism development of our region. [...] one that will take advantage of the local potential—people, landscape, history [...] This is our main goal: to develop a customer-friendly tourism in line with world trends, [ ... ] without forcing the visitors to do strange things or lying to them". (Se2)

"I do it, I mean, I run a cooperative so that I don't drink alcohol, because I'm terminally ill for the rest of my life. [...] I do it mainly for myself, not drinking, but also for others, to help them. It's an element of my therapy and my life strategy". (Se16)

"We were just long-term unemployed with problems; we wanted to get ourselves a job. And it was a problem for a long time for various reasons-our dependence, lack of offer on the market. (... ). We were then using social services in the city. Social Services sent us to a Social Integration Centre, where we trained up and six of us decided to open a social cooperative". (Se13)
\end{abstract}

Public support

"I would like to emphasise the role of EU funds or public funds in general. For us, they were the stimulus that enabled us to take new action. Thanks to them, we established a non-profit company and later a social cooperative, which I think of as the development of our statutory activity. This allowed us to expand the scale of professional activation of people with disabilities and improve the quality of our market offer. It would have been difficult to achieve these goals without external funding". (Se5)

Norms and values
"Our main goal is to raise the man who is most abandoned and somehow excluded; to raise him to a level
where he becomes independent, useful, where he regains a sense of value and dignity. [...] We believe that in
every human being, somewhere deep down, there is a potential that simply needs to be extracted. At the centre
of our values has always been care for people, such solidarity values, responsibility for each other". (Se11)
"[ ... ] What motivated us to create a social enterprise was, first of all, the readiness to help. [ ... ], the need to
do something together, [...] the sense that it is fun to do something together, [...] that we feel good about each
other, that we like each other, that we like to be together, that we want to be together, that we not only want to
work with each other, but that we want to spend time together. [...] And somewhere in us, in the group of people
who started this activity a few years ago, there was such a strong belief in the value of common action". (Se15)

$$
\text { Self-fulfilment }
$$

"I wanted to do something sensible in my life; it means something good to make it really beneficial for people other than me and my family. And if it is possible to combine it with earning money, let's say it's possible to live one way or another, although it's not heaps of money, but it's possible to function as if it's enough [...] it's hard for me to imagine myself, for example, in some company, where it's just about making money". (Se11) "We do not put pressure on ourselves or our employees or subcontractors here. We do not negotiate totally hard-core terms of cooperation and so on. [...] We are the decision-makers, we have influence, we are not employees, [...] and someone only manages us. We have a responsibility, we are responsible for everything". (Se3) 
Table 2. Cont.

Random events

"The setting-up of the organisation coincided with my personal situation, my situation in life. I adopted a child and started to socialise in these circles. I got in touch with people who were dedicated to the mission of saving children. They have often experienced unemployment and they had to earn a living for these children by themselves, what the state provides for care is not enough, they have to work anyway, and on the other hand they were unemployed. [...] We have put all this together so that caring for children fits our needs, this region, where we lived in, and so we have formed our organisation". (Se4)

Social and family models

"When my parents started the foundation, I was one and a half years old [...] now my parents are seventy. We have to continue their mission. I have been watching this activity since childhood, I have grown up in it, it is natural for me; it is something that gives meaning to my life, and above all, many people need this kind of activity". (Se11)

Beliefs and ideas

"I have a mission from God to help these alcohol addicts, but it's how I help myself and live my life". (Se16)

"[ ... ] We have come up with the idea that running a business may be a form of generating income for the association for its statutory activity. That is, if the social business quote goes well unquote, if the income is good, then the social goal will be met, because the disabled will have jobs, and there will be additional funds for our various activities". (Se5)

Source: Own study.

\subsubsection{Social or Personal Advantages}

The analysis results show that none of the social entrepreneurs considered market deficits as the basic reason for their involvement in social enterprise. Instead, their decisions were influenced by social or individual needs in order to address various social problems, such as unemployment, addiction, homelessness or meeting social needs. Social needs are understood as Bradshaw (1972). The author distinguished five types of social needs: normative, perceptible, expressed, comparative and technical (Bradshaw 1972). Reasons associated with personal or social advantages predominated among the social entrepreneurs. One of the stimuli for social entrepreneurs was the readiness to address individual or group needs resulted from various problems related to health, life, family, addictions, and others, getting a job and obtaining remuneration, and thus financial security. Involvement in social enterprise development was also associated with health issues and personal well-being. The aspect of health and social reintegration was emphasised particularly by representatives of organisations supporting people with various disabilities and addictions. Owing to this, not only a workplace tailored to their abilities and commitments was guaranteed, but also their needs associated with therapy, treatment, offered support in accessing specialist care services, socialisation, etc. were addressed. The engagement of respondents in social enterprise development also resulted from the need to take into account personal health problems or limitations which were not recognised by traditional employers. An important factor for social entrepreneurs was their commitment to solving various problems identified in the local community. For example, the engagement of one of the social entrepreneurs resulted from the local development needs, i.e., promotion of the region and tourism development, including the economic prosperity of the local community.

\subsubsection{Public Support}

Another stimulus to undertake social enterprise activities was the availability of public support provided within the framework of both EU-funded projects and domestic programmes. This included financial tools (available in the form of non-refundable grants business start-ups, or repayable funds for the development of existing organisations) and a variety of services (consultancy, training, information). Those activities were targeted both to natural persons and organisations. The public support was primarily intended to strengthen social integration, combat marginalisation and exclusion of various citizen groups from the labour market and society. 


\subsubsection{Norms and Values}

These factors were also partly axiologically driven, and reflected the norms and values cherished by the social entrepreneurs. The respondents emphasised rules in society (e.g., solidarity, responsibility) and internal standards of conduct (e.g., cooperation).

\subsubsection{Self-Fulfilment}

The respondents emphasised also the importance of self-fulfilment, which was offered by a sense of working towards 'higher goals'. This was justified by satisfaction, professional fulfilment, facilitated gaining experience, development of new skills, or addressing new challenges. The respondents also highlighted that social enterprises offer an attractive space for professional development by creating jobs for themselves in accordance with their values. Moreover, the need for independence at work was emphasised by the representatives of social enterprises.

\subsubsection{Random Events}

Another reason for the engagement toward social activities was related to random events (contingencies). In the analysed cases, these included occupational problems, e.g., conflict with the previous employer, accident-related health problems, progressive illness, or personal decisions related to family life (e.g., child adoption). This required a change in lifestyle, place, or form of professional involvement, often associated with the emergence of new needs.

\subsubsection{Social and Family Models}

The driving factor behind the social activities also included community or family models, which influenced social involvement, choice of professional path or form of activity. For example, the representative of Se11, when he joined the organisation founded by his parents, he treated it as something natural, which constituted a value in itself.

\subsubsection{Beliefs and Ideas}

Finally, beliefs and ideas close the list of reasons indicated by social entrepreneurs as decisive to their involvement in social entrepreneurship. Two respondents are conscious and convinced of the mission as well as implementation of activities, i.e., the founder of a social cooperative in the construction industry, which concurrently supports the treatment of alcohol addiction of its members (Se16), and the founder of Se7, which operated in the marketing industry and employed young people with various health problems. The commitment to social entrepreneurship was also caused by ideas made by the interviewees. The analysis of the cases showed that the ideas and opinions of funders on the essence of social entrepreneurship, i.e., the combination of business principles with the passion for social impact can determine their strategic decisions and actions (Wolk 2008).

Moreover, the results of empirical research on the factors due to which the researched social entrepreneurs decided to become involved in social entrepreneurship were identified and summarized in Table 3. The analysis of the collected data indicates that the involvement in the social entrepreneurship was the result of a combination of personal factors and external, contextually embedded factors (Jilinskaya-Pandey and Wade 2019; Stephan and Drencheva 2017; Korunka et al. 2003). The reasons were quite individualised to each respondent. The factors determining the involvement of social entrepreneurs varied and could not be reduced to a single approach. The interviews also differed in terms of the weight they attached to particular factors. The obtained results refer to the findings of other researchers. Several studies suggest that incentive factors play a crucial role in emergence of social enterprises, e.g., (Yitshaki and Kropp 2015; Germak and Robinson 2014; Ruskin and Webster 2011; Miller et al. 2012; Perrini and Vurro 2006; Nga and Shamuganathan 2010; Lukes and Stephan 2012). They indicated the importance of various factors analysed according to different theoretical approaches and classified to diverse typologies, e.g., pull and push factors 
(Yitshaki and Kropp 2015) or external and internal factors (Perrini and Vurro 2006). Polish researchers also pointed the importance of environmental factors influencing involvement in social entrepreneurship (Bogacz-Wojtanowska et al. 2014; Florczak 2016; Kurleto 2016). The study of Bogacz-Wojtanowska et al. (2014) showed that the involvement and success of social enterprises depends on many internal factors (e.g., business activity, number of customers, product quality) as well as external, environmental factors (e.g., nature, scope and forms of public support). The authors draw attention to the need for better adjustment of financial support by public funds to the needs of social enterprises, in particular, by measuring the effectiveness of the public grants for activities that contribute to socio-economic development at the local level and foster the employment of disadvantaged people in the labour market. Ciepielewska-Kowalik et al. (2015) stressed institutional and historical context for the emergency and development of social enterprises, indicated legal aspects (legislation on the NGOs and cooperatives activities) and financial and public policies. In the research carried out by Wronka (2009) "motivation and involvement of people employed in the organization" was considered as the second most important of the 26 analysed success factors for social economy organizations. The key success factors identified by the author included leadership, strong leader, favourable legal solutions, attractiveness and innovativeness of the offer, management knowledge, personal characteristics of employees who have contact with the client, cooperation with public sector organisations, social capital, involvement of the local community, and maintaining and making available accurate financial records.

Table 3. Influencing factors of the involvement in social entrepreneurship.

\begin{tabular}{|c|c|}
\hline Specifications & Influencing Factors \\
\hline $\begin{array}{l}\text { - } \quad \text { to solve problems identified in the local community } \\
\text { - } \quad \text { socialization of groups excluded from the labor market and society } \\
\text { - } \quad \text { gaining job, new skills } \\
\text { - } \quad \text { support for therapy and access to specialist care services }\end{array}$ & - $\quad$ Social and personal advantages \\
\hline $\begin{array}{ll}\text { - } & \text { financial tools (grants, loans) } \\
\text { - } & \text { services (consultancy, training, information) }\end{array}$ & - $\quad$ Public support \\
\hline $\begin{array}{ll}\text { - } & \text { rules in society (e.g., solidarity, responsibility) } \\
\text { - } & \text { internal standards of conduct (e.g., cooperation) }\end{array}$ & - $\quad$ Norms and values \\
\hline $\begin{array}{l}\text { - } \quad \text { the need for independence } \\
\text { - } \quad \text { satisfaction in work } \\
\text { - } \quad \text { taking up new challenges }\end{array}$ & - $\quad$ Self-fulfilment \\
\hline $\begin{array}{ll}\text { - } & \text { accident } \\
\text { - } & \text { deterioration of health } \\
\text { adoption of a child }\end{array}$ & - Random events \\
\hline - the social commitment of family members & - $\quad$ Social and family models \\
\hline $\begin{array}{ll}\text { - } & \text { perception } \\
\text { - } & \text { calling }\end{array}$ & - $\quad$ Beliefs and ideas \\
\hline
\end{tabular}

Source: Own study.

\subsection{The Institutional Context of Engagement in Social Entrepreneurship}

The following considerations address the second research question: how does the institutional environment affect the engagement in social entrepreneurship in Poland? The research analysis was based on the conceptual framework adopted from North $(2005,2017)$, presented in Figure 1 . The factors behind decisions to engage in social enterprises, identified by empirical research, can be explained by institutional theory, particularly in reference to North's findings. He stressed the critical function of institutions, which create, define and limit people's behaviour. The scope of the study and significance of different factors enable an analysis from the institutional perspective. 
In line with this, the identified factors of involvement in social entrepreneurship can be explained by formal and informal institutions as well as their characteristics, as illustrated in Table 4 . Factors such as social and personal advantages, random events, norms and values, social and family models, self-fulfilment, beliefs, and ideas can be considered in the context of socially sanctioned norms of conduct or mental models characterizing a social entrepreneur. These factors refer to the unwritten social and cultural principles and can be analysed from the perspective of informal institutions. In turn, a factor related to the public support was a result of legal regulations, which indicates a formal institution. Additionally, attention should be paid to the ways in which the institutions are implemented and enforced. They differ depending on the type of institutions.

Table 4. Institutional factors on engagement in the social entrepreneurship.

\begin{tabular}{|c|c|c|}
\hline Factors & Institutions & Enforcement of the Institutions \\
\hline $\begin{array}{l}\text { Social and personal advan } \\
\text { Random events } \\
\text { Norms and values } \\
\text { Social and family models } \\
\text { Self-fulfilment } \\
\text { Beliefs and ideas }\end{array}$ & Informal & $\begin{array}{l}\text { Self-control of individuals, } \\
\text { informal social control }\end{array}$ \\
\hline Public support & Formal & $\begin{array}{l}\text { Codified rules laid down in } \\
\text { documents by public decision-makers }\end{array}$ \\
\hline
\end{tabular}

The results point out that the engagement of individuals in social entrepreneurship was determined by personal factors (e.g., norms, beliefs, patterns, needs) as well as formal, external factors (e.g., public support). The institutional approach allows a broader analysis of the activities of social entrepreneurs not only in the context of their needs and social problems, but also taking into account the situational context in which decisions to set up a social enterprise are taken. Several studies suggest that institutional factors play a crucial role in the involvement of social entrepreneurs (e.g., Urbano et al. 2010, 2017; Ferri 2014; Estrin et al. 2013). Therefore, the presented findings justify the following theoretical proposition.

(1) The decisions of individuals regarding the engagement in social entrepreneurship are determined by the combination of social and internal norms of conduct and legal regulations.

The involvement in social entrepreneurship can be influenced by a combination of different factors. From an institutional perspective, the attention was first drawn to informal institutions. Covering a wide range of activities, they affect the behaviour of individuals in a natural way, because they are more deeply embedded than formal institutions. Hence, North (2017) points to their pervasiveness in society.

In this case, the activity based on informal institutions constituted an extension, elaborations and modification of the existing formal rules (North 2017). The involvement of social entrepreneurs resulted from the need to intervene in problem areas, which receive little, insufficient or no support from the state or other organizations. Actions undertaken in social enterprises resulted from the objective needs and expectations which reflected economic difficulties associated with the labour market, changes involving the family life, civilisational changes resulting in an increase in the incidence of addictions, mental disorders, isolation, or random events (Leś 2013; Urbano et al. 2010).

At the same time, the activity of social entrepreneurs indicated the socially sanctioned norms of behaviour (North 2017) associated with e.g.,

- " "taking responsibility for those who have it uphill all the way" (Se19);

- "concern for man in the name of solidarity values, responsibility for one another" (Se11).

Involvement of social entrepreneurs was also determined by internally enforced standard of conduct (North 2017), subjective factors, such as beliefs and ideas about work, life purposes, and the way of running a business, etc. Due to the opportunity for activities related to the own needs and 
values, e.g., the work conditions, teamwork, career development, the concept of social enterprise was an attractive business model for the investigated respondents.

The study also showed the importance of formal institutions defined as public support for involvement in social entrepreneurship. Public support included access to financial and non-financial resources together with rules for their implementation, e.g., the specific legal arrangements at national level in order to make resources available for the creation and development of social enterprises. Thus, the study confirmed the importance of public mechanisms as a key factor in the development of social enterprises, which is characteristic for social entrepreneurship in the European context (Pestoff and Hulgård 2015; Defourny and Nyssens 2010).

The research analysis points to a difference in the factors of social entrepreneurs who represent social enterprises from the so-called 'good practices' group and those in bankruptcy or liquidation, respectively. The representatives of the former group (e.g., S5, Se11, Se15) strongly emphasised the importance of informal institutions. Standards and values (e.g., cooperation, responsibility), and seeking self-fulfilment were important for their decision to set up a social enterprise as well as further activities. Respondents from this research group were characterised by commitment and interest in the outcomes achieved, including sustainability and development of their enterprises. The achieved goals, "successes" and outcomes strengthened their commitment and inspired them to keep going. Public support was the main reason for engaging in social entrepreneurship among those social enterprises which went bankrupt, were in liquidation, or faced economic difficulties (e.g., Se8, Se18). The respondents emphasised the importance of factors related to the use of available financial resources, which offered an opportunity to improve their occupational situation and accomplish personal goals. This group of respondents was characterised by short-term thinking and a similar business approach with less interest in the outcomes.

On the one hand, research confirms that access to financial resources is one of the key factors for the creation and development of social enterprises (Smith and Darko 2014; Sharma 2015; Gandhi and Raina 2018). At the same time, the process of effective resource mobilization can be particularly critical for social enterprises (Desa and Basu 2013). The findings of the European Commission, which is reviewing social enterprise ecosystems in 28 EU Member States and Switzerland, indicated that high dependence on the public sector, difficulties in accessing external financing and the lack of specialised services and support for business development, the lack of a supportive policy are one of the main factors limiting the take-up and expansion of social enterprise activity in Europe (European Commission 2015). Enabling social enterprises to access adequate finance means in practice a smart combination of demand and supply side of finance (Varga and Hayday 2016).

On the other hand, the findings of the study stress the importance of 'soft rules' and standards of behaviour maintained by the individuals themselves (Wilkin 2016) for social enterprises. Their role is repeatedly highlighted in institutional literature (North 2017). The formal or informal institutions generate various incentives for social entrepreneurs. These institutions influence the type, direction and intensity of social and economic activity. The system of institutions should be treated not as a set of different rules, but as a complex system that generates stimulants or destimulants of actions of varying strength. The effect of some institutions may be strengthened or weakened by others (Gruszewska 2017). The results indicate that informal institutions (norms and values, social and family models, self-fulfilment, beliefs, and ideas) are important at the stage of creating social enterprises as well as at the stage of further activity. The factors influencing of the involvement in social entrepreneurship may also affect the obtained results.

The findings are in line with the conclusion of Urbano et al. (2010). They pointed to the role of informal institutions, which affect not only the emergence of social enterprises in Catalonia but also their implementation. Based on a study in 49 countries, Ferri (2014) demonstrated that informal institution (socio-cultural factors) are more important for social entrepreneurial process than formal ones (public spending and access to funding). In line with this, given the institutional economics perspective the following theoretical proposition can be formulated. 
(2) The involvement in social entrepreneurship stimulated mainly by formal institutions in the form of public support is an insufficient factor for the creation of effective social enterprises.

Public programmes associated with the availability of the necessary financial and other resources made it possible to establish social enterprises. On the one hand, actions at the public decision-maker level were aimed at stimulating entrepreneurial activity with a social objective. On the other hand, it should be noted that the rules and conditions of access to support social enterprises motivated both those genuinely interested in such a form of activity, as well as those who exploited the available opportunities and resources in an instrumental manner. Public financial support made it possible to implement planned and well-thought-out activities. At the same time, the available support 'awakened' the entrepreneurship of people who had never intended to become entrepreneurs. Additionally, the respondents did not hesitate to admit that they used the available support by chance or in order to fund their private interests and needs.

Ultimately, their choice was largely determined by financial incentives available to social enterprises, despite the founders' insufficient knowledge of relevant legal regulations and principles of operation, and often the negative opinion about this form of activity. This approach can be illustrated by the statement made by the representative of Se4, who said,

"Because it was possible to obtain a grant to set up a business. If the same grant could be obtained with a different legal form, we would have no reason to set up this complex organisational structure. We have already had one organisation. Many social enterprises were established in this way because of the the available grants". (Se4)

A similar factor was indicated by social entrepreneurs as well as stakeholders who pointed out that some business plans were devised specifically in order to use the EU funds:

- "Grant considerations only determined the choice of this form of operation. [...] We knew what we wanted to do and how we wanted to do it, for us it was only a form of achieving our goals". (Se7)

- "Many of our beneficiaries had no intention to become social entrepreneurs. These business plans were specifically created in order to obtain EU funding". (S6)

From the point of view of the interviewed stakeholder, this led not only to the establishment of enterprises 'on a trial basis' but also indicated an insufficient commitment of their founders. As a result, a number of the social enterprises survived the minimum operating period required by the subsidy contract and then went bankrupt or continued the social business without any official or content-related action. Another interviewed stakeholders pointed out the insufficient planning and effectiveness of publicly funded activities and poor preparation of future social entrepreneurs for market activities:

"If the cooperative members [...] obtained a grant and know that all they have to do is not fail for a year and spend money on what they have planned, then, in fact, many of these cooperatives were set up according to the principle 'let's try and see if we succeed' [ ... ]". (S3)

In conclusion, the 'rules of the game' for the development of social enterprises in Poland were defined by both, the codified rules specified in documents by public decision-makers and informal social control and self-control by social entrepreneurs. As already mentioned, the informal institutions refer to unwritten social and cultural principles while formal institutions are established by law. Their observation is based on formal control but also depends on internally enforced standards of conduct by individuals. The examined respondents complained about the low quality of regulations in the area of funding social enterprises and insufficient effectiveness of their implementing. At the same time, the lack of social control mechanisms of social enterprises (e.g., through measuring and communicating social impact by means of social reports) was indicated. The importance of the quality of regulations and mechanisms concerning the public support for the creation and operation of social enterprises in Poland was identified in different evaluation reports (Stronkowski et al. 2013) and other 
national studies (Korycki 2015). The institutional framework for social cooperatives (as vital part of social entrepreneurship) in Poland was assessed by Starnawska (2014) as difficult and of low quality. The author distinguished three categories of social entrepreneurs' behaviours that relate to the complex institutional environment—-networking, diversification, and the blurring of borders. Thus, the behavior of social entrepreneurs reflects their presence in the informal economy. Therefore, from the institutional point of view, the findings lead to the following theoretical proposition:

(3) The low quality of financial and nonfinancial support procedure on social activities may mitigate individual involvement of social entrepreneurs.

\section{Conclusions}

The growing importance of social entrepreneurship both in the world and in Poland is related to several factors. First, it offers solutions that contribute to the reduction or minimization of social problems, activate unused resources, and introduce various types of innovative and efficient solutions to accelerate social change. Thus, social entrepreneurship contributes to the improvement of the state and socio-economic development. Second, it is necessary to point out the problems and the modernization processes taking place in the public administration. Therefore, the role of social entrepreneurship as a potential provider of public services in the light of limitations and inefficiency of the public sector regarding financing and meeting social needs and changes in public services provision should be recognised. Thus, the emphasis from the government toward governance should be shifted, where the role of administration is less the provision of services and more often their delegation (Leś 2013; Hausner 2008; Sharir and Lerner 2006). Third, the intensification of social problems and the emergence of the new ones (precariat, aging of societies, ecological problems, etc.) cause an increase in demand for social services. This is a premise to seek new forms and methods of operation by social organizations, including entrepreneurial solutions that offer various forms of income generation and contribute to their sustainability. Due to the role of social enterprises in the economy, state, and society, there is a further need for research and analysis in this area.

The aim of the study was to identify and analyse factors influencing the involvement of individuals in social enterprises in Poland from an institutional economics perspective. Using of empirical data and a case study methodology, three theoretical propositions have been developed. The propositions can be considered as a significant contribution that expands the existing knowledge on influencing factors on involvement in social entrepreneurship.

The analysis demonstrated that the decision to engage in social enterprises was led by several combined reasons. In total, seven factors for involvement of individuals in social enterprises were identified: social and personal advantages, public support, random events, norms and values, self-fulfilment, social and family models, and beliefs and ideas. The institutional approach allows a broader analysis of social entrepreneur activities not only in the context of their needs and social problems, but also taking into account the situational context in which decisions to set up a social enterprise are taken. On the one hand, a context of social enterprises is created by informal institutions, i.e., social values, models of conduct and beliefs. On the other hand, formal rules also play a significant role in this phenomenon. The study confirmed the importance of combination of formal and informal institutional factors for the involvement of individuals in social enterprises (proposition 1). Next, the findings of the study emphasises indicated, that the involvement in social entrepreneurship, stimulated mainly by formal institutions, understood as public support in financial and non-financial form, can be seen as an insufficient factor for the creation of effective social enterprises (proposition 2). Moreover, the study showed the crucial importance of the ways of implementing and enforcing institutions, which is rarely analyzed in the literature. This demonstrates that the low quality of financial and nonfinancial support procedure on social activities may mitigate individual involvement of social entrepreneurs (proposition 3).

The research analysis leads to the observation that the institutional environment affects the involvement of individuals in social enterprise at the stage of creating an organisation (motivation 
stage), as well as at the stage of conducted activities, and thus influences the results contributing to the development or limiting the conducted activities. The identified institutional factors included the system of positive and negative incentives (North 2017), stimulated and limited the opportunities for the development of social entrepreneurship in Poland.

The implications of the results are important both for theory and practice. First, the empirical analysis contributes to a better understanding of involvement in social entrepreneurship by exploring the factors influencing the activity of social entrepreneurs. It shows that the involvement of individuals in social entrepreneurship should be considered holistically, by showing various factors that affect the involvement of individuals. At the same time, the study broadens the definition of social entrepreneurs, understood as a person who creates enterprises to meet social objectives rather than generate personal financial profits (Shaw and Carter 2007) by showing the importance of other influencing factors, e.g., personal advantages, beliefs. Second, the findings of the research contribute to knowledge about the role of institutional factors in the creation of social enterprises. Given the institutional perspective, the analysis provides new insights into the factors for individual engagement in this area. As a result of the research, the importance of norms, values, patterns, i.e., informal institutions embedded in culture, which shape the choices made by individuals and determine the effects of social activities, has been pointed out. Analysing the importance of institutional factors provides new insights and knowledge about the studied phenomenon. It indicates the need to include in further research studies the institutional context.

Moreover, the study results are important for public decision-makers to design good quality solutions supporting the creation and development of social enterprises. High quality institutions are those that cause socially desirable behaviours of social and economic organizations (Rodrik 2011). Thus, it indicates that the essence of regulation is just as important as the way it is implemented. In this context, the process of monitoring and evaluation of solutions implemented by decision makers becomes more important, as well as the necessity to take into account the conclusions from this study.

Based on this research, different recommendations for further analyses with a view to gaining a better understanding of the phenomenon can be indicated. Further investigation in Poland and countries with similar backgrounds may focus on the performance of social enterprises (in terms of their stability, sustainability, and/or social impact) in the context of different types of factors that characterise social entrepreneurs. According to North (2005) and other institutional scholars (e.g., Helmke and Levitsky 2004), an important direction of research on social entrepreneurship development may include coherence between formal (legal regulations) and informal institutions (social norms and values, mental models). An analysis of the quality of institutions which provide the conditions for the development of social activities may also be of interest. In addition, further research may concern the examination of how the ethical nature of social entrepreneurs (the values they adhere to) differentiates the results obtained by social enterprises.

The conducted research has some limitations. First, the analysis results are not representative because of the qualitative approach. Hence, the findings cannot be generalised to the entire social entrepreneurship sector in Poland. Second, the study focuses only on the Polish experiences, which limits its international applicability. Third, the analysis concerned the institutions, which are difficult to measure in terms of their manifestations, quality and strength of impact.

Funding: This research was funded by the Ministry of Science and Higher Education of the Republic of Poland within the "Regional Initiative of Excellence" Programme for 2019-2022 (Project no.: 021/RID/2018/19).

Conflicts of Interest: The author declares no conflict of interest. The funder had no role in the design of the study; in the collection, analyses, or interpretation of data; in the writing of the manuscript, or in the decision to publish the results. 
Appendix A. Social Enterprises Profiles and Sample Characteristics

\begin{tabular}{|c|c|c|c|c|c|}
\hline $\begin{array}{c}\text { Social } \\
\text { Enterprise (Se) }\end{array}$ & Legal Form & $\begin{array}{c}\text { Year of } \\
\text { Foundation }\end{array}$ & Founder Type & Scope of Social Activity & Scope of Business Activity \\
\hline Se1 & Social cooperative & 2005 & Natural person & Professional and social activation of people with disabilities & Services: IT and training \\
\hline Se2 & Association & 2009 & Natural person & $\begin{array}{l}\text { Local development, promotion of tourism, development of } \\
\text { entrepreneurship among inhabitants }\end{array}$ & $\begin{array}{l}\text { Promotion and sale of local products, } \\
\text { tourist information }\end{array}$ \\
\hline Se3 & Social cooperative & 2012 & Natural person & Employment, community service activities & Services: advertising, printing, sewing, training \\
\hline Se4 & Social cooperative & 2014 & Legal person & $\begin{array}{l}\text { Professional activation of women from rural areas, integration } \\
\text { of parents adopting children, development of local community }\end{array}$ & Services: caring for children, old people \\
\hline Se5 & $\begin{array}{l}\text { Non-profit } \\
\text { company }\end{array}$ & 2007 & Legal person & Professional and social activation of people with disabilities & $\begin{array}{l}\text { Services: catering and restaurant; rental of } \\
\text { training rooms }\end{array}$ \\
\hline Se6 & Social cooperative & 2014 & Natural person & Professional and social activation of excluded groups & Services and facilities: catering and restaurant \\
\hline Se7 & Social cooperative & 2011 & Natural person & Professional and social activation of excluded groups & Services: advertising, online promotion, PR \\
\hline Se8 & Foundation & 2017 & Natural person & Professional activation of excluded persons & Restaurant services \\
\hline Se9 & Social cooperative & 2007 & Natural person & Professional activation of excluded persons & Services: café, cleaning services \\
\hline Se10 & Social cooperative & 2011 & $\begin{array}{l}\text { Natural person, } \\
\text { legal person }\end{array}$ & $\begin{array}{l}\text { Professional and social activation of people with disabilities; } \\
\text { promotion of the art of people with disabilities }\end{array}$ & Services: craftwork \\
\hline Se11 & Foundation & 1989 & Natural persons & $\begin{array}{l}\text { Professional and social activation of excluded groups } \\
\text { (homeless people, immigrants) }\end{array}$ & Agricultural holding \\
\hline Se12 & Social cooperative & 2012 & Natural person & Professional activation of the unemployed & Services: childcare (nursery, kindergarten) \\
\hline Se13 & social cooperative & 2007 & Natural person & Professional activation of excluded persons & Services: cleaning and maintenance of green areas \\
\hline Se14 & Social cooperative & 2009 & $\begin{array}{l}\text { Community, } \\
\text { NGO }\end{array}$ & $\begin{array}{l}\text { Professional activation of excluded persons, development of } \\
\text { local community }\end{array}$ & Services: food and beverage, training \\
\hline Se15 & Foundation & 2007 & $\begin{array}{l}\text { Legal person, } \\
\text { NGO }\end{array}$ & $\begin{array}{l}\text { Activation of the unemployed and persons threatened by social } \\
\text { exclusion through work and education }\end{array}$ & $\begin{array}{l}\text { Services and facilities: carpentry, catering, laundry, } \\
\text { training; Production: woodworking products }\end{array}$ \\
\hline Se16 & Social cooperative & 2011 & $\begin{array}{l}\text { Legal person, } \\
\text { NGO }\end{array}$ & $\begin{array}{l}\text { Professional and social activation of excluded people } \\
\text { (substance addicts) }\end{array}$ & $\begin{array}{l}\text { Services: repair, cleaning, construction, care and } \\
\text { support services }\end{array}$ \\
\hline Se17 & Social cooperative & 2013 & Natural person & Professional and social activation of people with disabilities & Services: maintenance of green areas \\
\hline
\end{tabular}




\begin{tabular}{cccccc}
\hline $\begin{array}{c}\text { Social } \\
\text { Enterprise (Se) }\end{array}$ & Legal Form & $\begin{array}{c}\text { Year of } \\
\text { Foundation }\end{array}$ & Founder Type & Scope of Social Activity & Scope of Business Activity \\
\hline Se18 & Social cooperative & 2015 & Natural person & Professional and social activation of the unemployed & Services: maintenance of green areas \\
\hline Se19 & $\begin{array}{c}\text { Non-profit } \\
\text { company }\end{array}$ & 2013 & $\begin{array}{c}\text { Legal person, } \\
\text { NGO }\end{array}$ & $\begin{array}{c}\text { Promotion of culture, art, integration of the } \\
\text { academic community }\end{array}$ & Food and beverage services \\
\hline Se20 & Foundation & 1990 & Natural person & Activation and reintegration of adults with disabilities & Services: organisation of cultural events \\
\hline Se21 & Foundation & 2015 & Legal person & Social and professional rehabilitation of people with disabilities & Craftwork \\
\hline Se22 & $\begin{array}{c}\text { Labour } \\
\text { cooperatives }\end{array}$ & 2014 & Natural person & Promotion of social activity & Services: consulting and advisory services \\
\hline
\end{tabular}

Source: Own study.

\section{Appendix B. Stakeholders' Profiles and Sample Characteristics}

\begin{tabular}{|c|c|c|c|}
\hline Stakeholder (S) & Represented Organisation/Sector & Scope of the Organisation's Activity & $\begin{array}{l}\text { Interviewee Function } \\
\text { in the Organisation }\end{array}$ \\
\hline S1 & Public administration, regional level/Public & Coordination of social economy policies in the region & CEO \\
\hline S2 & Public administration, regional level/Public & $\begin{array}{l}\text { Research and analytical activities, including those related to SE, cooperation with social } \\
\text { economy support centres }\end{array}$ & CEO \\
\hline S3 & Loan and guarantee organisation/Social & Financial services (advisory services, loans, guarantees) for the social and private sectors & CEO \\
\hline S4 & Social economy support centre/Social & Consultancy, training, information, incubation of ES entities & CEO \\
\hline S5 & Public administration, regional level/Public & $\begin{array}{l}\text { Coordination of social economy policy in the region; running a social economy support } \\
\text { centre (including counselling, grants for cooperatives) }\end{array}$ & $\begin{array}{l}\text { Consultant, expert, } \\
\text { researcher on SE }\end{array}$ \\
\hline S6 & Social economy support centre/Social & $\begin{array}{l}\text { Supporting social enterprises and other social economy entities through consultancy, } \\
\text { training workshops, information and incubation }\end{array}$ & Manager \\
\hline S7 & Municipal/Public Office & Supervision and coordination of the municipality's activities (including social issues) & CEO \\
\hline S8 & Union of labour cooperatives/Private & $\begin{array}{l}\text { Support for individuals and organisations interested in creating and developing } \\
\text { cooperative activities (consulting, financial support, ocean of cooperative activities) }\end{array}$ & CEO \\
\hline S9 & Financial sector/Private & Loans and guarantees to the social economy sector, commercial entities and individuals & $\mathrm{CEO}$ \\
\hline S10 & Municipal Labour Office/Public & $\begin{array}{l}\text { Professional activation of the unemployed; non-refundable grants for the creation of } \\
\text { social cooperatives }\end{array}$ & $\mathrm{CEO}$ \\
\hline
\end{tabular}

Source: Own study. 


\section{References}

Aidis, Ruta, Saul Estrin, and Tomasz Mickiewicz. 2007. Entrepreneurial Entry: Which Institutions Matter? IZA Discussion Papers, No. 4123. Available online: https://www.econstor.eu/bitstream/10419/35677/1/599380896. pdf (accessed on 30 December 2019).

Austin, James, Jane Wei-Skillern, and Howard Stevenson. 2006. Social and Commercial Entrepreneurship: Same, Different, or Both? Rochester. Scholarly Paper. New York: Social Science Research Network, Available online: https://papers.ssrn.com/abstract=1501555 (accessed on 13 July 2019).

Bacq, Sophie, and Frank Janssen. 2011. The multiple face of social entrepreneurship: A review of definitional issues based on geographical and thematic criteria. Entrepreneurship E Regional Development 23: 373-403.

Bogacz-Wojtanowska, Ewa, Izabela Przybysz, and Małgorzata Lendzion. 2014. Sukces i Trwałość Ekonomii Społecznej w Warunkach Polskich. Warszawa: Fundacja Instytut Spraw Publicznych.

Bradshaw, Jonathan. 1972. Taxonomy of social need. In Problems and Progress in Medical Care: Essays on Current Research, 7th ed. Edited by Gordon McLachlan. London: Oxford University Press, pp. 71-82.

Brock, Debbi, and Marina Kim. 2011. Social Entrepreneurship Education Resource Handbook. Available online: https://ssrn.com/abstract=1872088 (accessed on 13 April 2019).

Brooks, Arthur C. 2009. Social Entrepreneurship. A Modern Approach to Social Value Creation. New Yersey: Pearsons Prentice Hall.

Brouard, François, and Sophie Larivet. 2010. Essay of Clarification and Definitions of related concepts of Social Enterprise. Social Entrepreneur and Social Entrepreneurship. In Handbook of Research on Social Entrepreneurship. Edited by Alain Fayolle and Harry Matlay. Northhampton: Edward Elgar Publishing, pp. 29-56.

Chell, Elizabeth, Katerina Nicolopoulou, and Mine Karataş-Özkan. 2010. Social entrepreneurship and enterprise: International and innovation perspectives. Entrepreneurship \& Regional Development 22: 485-93.

Ciepielewska-Kowalik, Anna, Bartosz Pieliński, Marzena Starnawska, and Aleksandra Szymańska. 2015. Social Enterprise in Poland: Institutional and Historical Context. ICSEM Working Papers, No 11, The International Comparative Social Enterprise Models, Liege, Belgium. Available online: https://www.iap-socent.be/sites/ default/files/Poland\%20-\%20Ciepielewska-Kowalik\%20et\%20al.pdf (accessed on 19 April 2019).

Creswell, John W. 2013. Projektowanie Badań Naukowych. Metody Jakościowe, Ilościowe i Mieszane. Wydanie 1. Kraków: Uwydawnictwo Uniwersytetu Jagiellońskiego.

Dacin, Peter A., Tina Dacin, and Margaret Matear. 2010. Social Entrepreneurship: Why We Don't Need a New Theory and How We Move Forward from Here. Academy of Management Perspectives 24: 37-57.

Davis, Lance E., and Douglas C. North. 1971. Institutional Change and American Economic Growth. Cambridge: Cambridge University Press.

Dees, Gregory J. 2001. The Meaning of Social Entrepreneurship. Working Paper. Stanford, CA, USA: Stanford University.

Defourny, Jacques. 2001. From Third Sector to Social Enterprise. In The Emergence of Social Enterprise. Edited by Carlo Borzaga and Jacques Defourny. London and New York: Routledge, pp. 1-18.

Defourny, Jacques, and Marte Nyssens. 2010. Conceptions of Social Enterprise and Social Entrepreneurship in Europe and the United States: Convergences and Divergences. Journal of Social Entrepreneurship 1: 32-53. [CrossRef]

Dembińska, Aleksandra. 2012. Metody jakościowe wobec problematyki przedsiębiorczości. In Przedsiębiorczość. Źródła i Uwarunkowania Psychologiczne. Edited by Zofia Ratajczak. Warszawa: Difin, pp. 214-33.

Denzin, Norman K. 1978. The Research Act: A Theoretical Introduction to Sociological Methods. New York: McGraw-Hill.

Denzin, Norman K., and Yvonna S. Linclon, eds. 2009. Wprowadzenie. Dziedzina i praktyka badań jakościowych. In Metody Badań Jakościowych. Warszawa: Wydawnictwo Naukowe PWN, pp. 19-76.

Desa, Geoffrey, and Sandip Basu. 2013. Optimization or bricolage? Overcoming resource constraints in global social entrepreneurship. Strategic Entrepreneurship Journal 1: 26-49. [CrossRef]

Eriksson, Päivi, and Anne Kovalainen. 2008. Qualitative Methods in Business Research. London: Sage.

Estrin, Saul, Tomasz Mickiewicz, and Ute Stephan. 2013. Entrepreneurship Social Capital, and Institutions: Social and Commercial Entrepreneurship across Nations. Entrepreneurship Theory and Practice 37: 479-504. [CrossRef] 
European Commission. 2015. A Map of Social Enterprises and Their Eco-Systems in Europe. Synthesis Report. A Report Submitted by ICF Consulting Services, European Commission Directorate General for Employment, Social Affairs and Inclusion. Brussels: European Commission.

European Commission. 2016. Social Enterprises and Their Eco-Systems: A European Mapping Report. Updated Country Report: Poland, European Commission, Directorate-General for Employment, Social Affairs and Inclusion. Brussels: European Commission.

Ferri, Elisabeth. 2014. Social Entrepreneurship and Institutional Context: A Quantitative Analysis. Ph.D. Thesis, International Doctorate in Entrepreneurship and Management, The Autonomous University of Barcelona, Barcelona, Spain. Available online: https://ddd.uab.cat/record/129035 (accessed on 14 April 2019).

Flick, Uwe. 2011. Jakość w Badaniach Jakościowych. Warszawa: Wydawnictwo Naukowe PWN.

Florczak, Ewelina. 2016. Działalność przedsiębiorstw społecznych w Polsce. In Uwarunkowania Działalności Przedsiębiorstw Społecznych w Polsce. Edited by Jacek Brdulak and Ewelina Florczak. Warszawa: Oficyna Wydawnicza Uczelni Łazarskiego, pp. 84-148.

Furubotn, Eirik G., and Rudolf Richter. 2005. Institutions and Economic Theory. The Contribution of the New Institutional Economics. Ann Arbor: The University of Michigan Press.

Gandhi, Tanvi, and Rishav Raina. 2018. Social entrepreneurship: The need, relevance, facets and constraints. Journal of Global Entrepreneurship Research 8. [CrossRef]

Germak, Andrew J., and Jeffrey A. Robinson. 2014. Exploring the Motivation of Nascent Social Entrepreneurs. Journal of Social Entrepreneurship 5: 5-21. [CrossRef]

Granados, Maria L., Vlatka Hlupic, Elayne Coakes, and Souad Mohamed. 2011. Social enterprise and social entrepreneurship research and theory: A bibliometric analysis from 1991 to 2010. Social Enterprise Journal 7: 198-218. [CrossRef]

Gras, David M., Todd W. Moss, and G. Thomas Lumpkin. 2014. The use of secondary data in social entrepreneurship research: Assessing the field and identifying future opportunities. In Social Entrepreneurship and Research Methods. Research Methodology in Strategy and Management. Bingley: Emerald Group Publishing Ltd., vol. 9, pp. 49-75.

Gruszewska, Ewa. 2017. Instytucje formalne i nieformalne. Skutki antynomii. Prace Naukowe Uniwersytetu Ekonomicznego we Wroctawiu. Instytucje w Teorii i Praktyce 493: 36-50. [CrossRef]

Haugh, Helen. 2005. A research agenda for social entrepreneurship. Social Enterprise Journal 1: 1-12. [CrossRef]

Haugh, Helen. 2006. Social Enterprise: Beyond Economic Outcomes and Individual Returns. In Social Entrepreneurship. Edited by Johana Mair, Jeffrey Robinson and Kai Hockerts. London: Palgrave Macmillan UK.

Hausner, Jerzy. 2008. Zarzadzanie Publiczne. Warszawa: Wydawnictwo Naukowe Scholar.

Helmke, Gretchen, and Steven Levitsky. 2004. Informal Institutions and Comparative Politics: A Research Agend. Perspectives on Politics 2: 725-40. [CrossRef]

Herbst, Jan. 2008. Pole przedsiębiorczości społecznej w Polsce. In Ekonomia Społeczna w Polsce: Osiagnięcia, Bariery Rozwoju i Potencjał w Świetle Wyników. Edited by Jerzy Hausner and Anna Giza-Poleszczuk. Warszawa: Fundacja Inicjatyw Społeczno-Ekonomicznych, pp. 41-86.

Hoogendoorn, Brigitte, and Chantal Hartog. 2011. Prevalence and Determinants of Social Entrepreneurship at the Macro-Level. EIM Research Reports. Available online: https://core.ac.uk/download/pdf/6480306.pdf (accessed on 14 April 2019).

Hoogendoorn, Brigitte, Enrico Pennings, and Roy Thurik. 2010. What do we know about social entrepreneurship? An analysis of empirical research. International Review of Entrepreneurship 8: 71-112.

Hota, Pradeep Kumar, Balaji Subramanian, and Gopalakrishnan Narayanamurthy. 2019. Mapping the Intellectual Structure of Social Entrepreneurship Research: A Citation/Co-citation Analysis. Journal of Business Ethics. [CrossRef]

Jilinskaya-Pandey, Mariya, and Jeremy Wade. 2019. Social Entrepreneur Quotient: An International Perspective on Social Entrepreneur Personalities. Journal of Social Entrepreneurship 10: 265-87. [CrossRef]

Kerlin, Janelle A. 2012. Defining Social Enterprise across Different Contexts: A Conceptual Framework Based on Institutional Factors. Nonprofit and Voluntary Sector Quarterly 42: 84-108. [CrossRef]

Kerlin, Janelle A. 2017. Shaping Social Enterprise: Understanding Institutional Context and Influence. Bingley: Emerald Publishing Limited.

Kickul, Jill, and Thomas S. Lyons. 2012. Understanding Social Entrepreneurship: The Relentless Pursuit of Mission in an Ever Changing World. New York and London: Routledge. 
Kopyciński, Piotr. 2018. City Lab as a Platform for Implementing Urban Innovation: The Role of Companies. In International Entrepreneurship as the Bridge between International Economics and International Business: Conference Proceedings of the 9th ENTRE Conference and 5th AIB-CEE Conference. Edited by Krzysztof Wach and Marek Maciejewski. Cracow: Uniwersytet Ekonomiczny w Krakowie, pp. 257-74.

Korunka, Christian, Hermann Frank, Manfred Lueger, and Josef Mugler. 2003. The Entrepreneurial Personality in the Context of Resources, Environment, and the Startup Process-A Configurational Approach. Entrepreneurship Theory and Practice 28: 23-42. [CrossRef]

Korycki, Arkadiusz. 2015. Partnerstwo na rzecz instytucjonalizacji gospodarki społecznej. Partnerstwo na rzecz instytucjonalizacji gospodarki społecznej. Wywiad z Jerzym Hausnerem, Jerzym Wilkinem, Witoldem Kwaśnickim. Rozmowa z Jerzym Wilkinem. Społeczeństwo Obywatelskie. Badania. Praktyka. Polityka 2: 64-71.

Kurleto, Małgorzata. 2016. Model Przedsiębiorstwa Społecznego. Warszawa: Difin.

Leadbeater, Charles. 1997. The Rise of the Social Entrepreneurship. London: Demos.

Leś, Ewa. 2013. Organizacje Non Profit w Nowej Polityce Społecznej w Polsce na tle Europejskim. Warszawa: Oficyna Wydawnicza ASPRA-JR.

Lukes, Martin, and Ute Stephan. 2012. Entrepreneurs and leaders of non-profit organizations: Similar people with different motivations. Ceskoslovenska Psychologie 56: 41-55.

Lumpkin, G. Thomas, Todd W. Moss, David M. Gras, Shoko Kato, and Alejandro S. Amezcua. 2013. Entrepreneurial processes in social contexts: How are they different, if at all? Small Business Economics 40: 1-23. [CrossRef]

Mair, Johanna, and Ignasi Martí. 2004. Social Entrepreneurship: What are We Talking about? A Framework for Future Research. Working Paper No 546. Barcelona, Spain: IESE Business School, University of Navarra.

Mair, Johanna, and Ignasi Martí. 2006. Social entrepreneurship research: A source of explanation, prediction, and delight. Journal of World Business 41: 36-44. [CrossRef]

Małecka-Łyszczek, Magdalena. 2017. Wspótpraca Administracji Publicznej z Podmiotami Ekonomii Społecznej. Aspekty Prawnoadministracyjne. Warszawa: Wolters Kluwer.

Miller, Toyah L., Matthew G. Grimes, Jeffery S. McMullen, and Timothy J. Vogus. 2012. Venturing for Others with Heard and Head: How Compassion Encourages Social Entrepreneurship. Academy of Management Review 37: 616-40. [CrossRef]

Ministry of Labor and Social Policy. 2014. Krajowy Program Rozwoju Ekonomii Społecznej (National Social Economy Development Program). Monitor Polski, No. 811. Warszawa: Ministry of Labor and Social Policy, vol. 1.

Nga, Joyce Koe Hwee, and Gomathi Shamuganathan. 2010. The Influence of Personality Traits and Demographic Factors on Social Entrepreneurship Start up Intentions. Journal of Business Ethics 95: 259-82.

Nicholls, Alex. 2006. Social Entrepreneurship. New Models of Sustainable Change. Oxford: Oxford University Press.

Nicholls, Alex. 2010. The Legitimacy of Social Entrepreneurship: Reflexive Isomorphism in a Pre-Paradigmatic Field. Entrepreneurship Theory and Practice 34: 611-33. [CrossRef]

North, Douglas C. 1991. Institutions. The Journal of Economic Perspectives 5: 97-112. [CrossRef]

North, Douglas C. 1994. Economic Performance through Time. The American Economic Review 84: 359-68.

North, Douglas C. 2005. Understanding the Process of Economic Change. Princeton and Oxford: Princeton University Press.

North, Douglas C. 2017. Institutions, Institutional Change and Economic Performance, 29th ed. New York: Cambridge University Press.

Pacut, Agnieszka. 2018a. Trajektoria zmian przedsiębiorczości społecznej w Polsce. Ekonomia Społeczna 2: 7-15. [CrossRef]

Pacut, Agnieszka. 2018b. Social Entrepreneurship in Opinion of Company Leaders and Representatives of Stakeholders. Harvard Dataverse Database. [CrossRef]

Patton, Michael Q. 2015. Qualitative Research and Evaluation Methods, 4th ed. Thousand Oaks: Sage Publications.

Perrini, Franceso. 2006. The New Social Entrepreneurship. What Awaits Social Entrepreneurial Ventures? Cheltenham and Northhampton: Edward Elgar Publishing.

Perrini, Franceso, and Clodia Vurro. 2006. Social Entrepreneurship: Innovation and social change across theory and practice. In Social Entrepreneurship. Edited by Johanna Mair, Jeffrey Robinson and Kai Hockerts. London: Palgrave Macmillan UK.

Perrini, Franceso, Clodia Vurro, and Laura Costanzo. 2010. A process-based view of social entrepreneurship: From opportunity identification to scaling-up social change in the case of San Patrignano. Entrepreneurship $\mathcal{E}$ Regional Development 22: 515-34. 
Pestoff, Victor, and Lars Hulgård. 2015. Participatory Governance in Social Enterprise. 5th EMES International Conference on Social Enterprise, Helsinki. Available online: http: //emes.net/content/uploads/publications/participatory-governance-in-social-enterprise/ESCP-5EMES-40_ Participatory_Governance_Social_Enterprise.pdf (accessed on 15 April 2019).

Robinson, Jeffrey. 2006. Navigating Social and Institutional Barriers to Markets: How Social Entrepreneurs Identify and Evaluate Opportunities. In Social Entrepreneurship. Edited by Johanna Mair, Jeffrey Robinson and Kai Hockerts. London: Palgrave Macmillan UK, pp. 95-120.

Rodrik, Dani. 2011. Jedna Ekonomia, Wiele Recept. Globalizacja, Instytucje i Wzrost Gospodarczy. Warszawa: Wydawnictwo Krytyki Politycznej.

Romani-Dias, Marcello, Edson Sadao Iizuka, Elisa Rodrigues Alves Larroudé, and Aline Dos Santos Barbosa. 2018. Mapping of Academic Production on Social Enterprises: An international analysis for the growth of this field. International Review of Social Research 8: 156-71. [CrossRef]

Ruskin, Jennifer, and Cynthia M. Webster. 2011. Creating Value for Others: An Exploration of social Entrepreneurs' Motives, ANZAM 2011. Available online: www.anzam.org/wp-content/uploads/pdfmanager/463_ANZAM2011-125.PDF (accessed on 19 January 2020).

Sahasranamam, Sreevas, and M. K. Nandakumar. 2020. Individual capital and social entrepreneurship: Role of formal institutions. Journal of Business Research 107: 104-17. [CrossRef]

Sassmannshausen, Sean Patrick, and Christine Volkmann. 2016. The Scientometrics of Social Entrepreneurship and Its Establishment as an Academic Field. Journal of Small Business Management 56: 251-73. [CrossRef]

Seelos, Christian, and Johanna Mair. 2004. Social Entrepreneurship: The Contribution of Individual Entrepreneurs to Sustainable Development. Working Paper 553. Barcelona, Spain: University of Navarra. [CrossRef]

Sekliuckiene, Jurgita, and Eimantas Kisielius. 2015. Development of social entrepreneurship initiatives: A theoretical Framework. Procedia Social and Behavioral Sciences 213: 1015-19. [CrossRef]

Sharir, Moshe, and Miri Lerner. 2006. Gauging the success of social ventures initiated by individual social entrepreneurs. Journal of World Business 41: 6-20. [CrossRef]

Sharma, Venus. 2015. Identifying Constraints in Social Entrepreneurship Ecosystem of India: A Developing Country Context. Available online: https://ssrn.com/abstract=2729720 (accessed on 19 January 2020).

Shaw, Eleanor, and Sara Carter. 2007. Social entrepreneurship theoretical antecedents and empirical analysis of entrepreneurial processes and outcomes. Journal of Small Business and Enterprise Development 14: 418-34. [CrossRef]

Short, Jeremy, Todd W. Moss, and G. Thomas Lumpkin. 2009. Research in Social Entrepreneurship: Past Contributions and Future Opportunities. Strategic Entrepreneurship Journal 3: 161-94. [CrossRef]

Smith, William, and Emily Darko. 2014. Social Enterprise: Constraints and Opportunities-Evidence from Vietnam and Kenya. London: Oerseas Development Institute, Available online: https://www.odi.org/sites/odi.org.uk/files/ odi-assets/publications-opinion-files/8877.pdf (accessed on 30 October 2019).

Stake, Robert E. 2009. Jakościowe studium przypadku. In Metody Badań Jakościowych. Edited by Norman K. Denzin and Yvonne S. Lincoln. Warszawa: Wydawnictwo Naukowe PWN, pp. 623-54.

Starnawska, Marzena. 2014. Zachowanie poprzez sieciowanie w przedsiębiorczości społecznej w odpowiedzi na trudne otoczenie instytucjonalne—przypadek pięciu spółdzielni socjalnych. Problemy Zarzadzania 12: 97-116.

Stephan, Ute, and Andreana Drencheva. 2017. The person in social entrepreneurship: A systematic review of research on the social entrepreneurial personality. In The Wiley Handbook of Entrepreneurship. Edited by Gorkan Ahmetoglu, Tomas Chamorro-Premuzic, Bailey Klinger and Tessa Karcisky. Chichester: Wiley-Blackwell, pp. 205-29.

Stephan, Ute, Lorraine M. Uhlaner, and Christopher Stride. 2015. Institutions and social entrepreneurship: The role of institutional voids, Institutional Support and Institutional Configurations. Journal of International Business Studies 46: 308-31. [CrossRef]

Stronkowski, Piotr, Magdalena Andrzejewska, Klaudia Łubian, Karolina Cyran-Juraszek, and Anna Matejczuk. 2013. Badanie Ewaluacyjne pt. Ocena Wsparcia w Obszarze Ekonomii Społecznej Udzielonego ze Środków EFS w Ramach PO KL; Coffey International Development. Warszawa: Ministerstwo Infrastruktury i Rozwoju. Available online: www.efs.2007-2013.gov.pl/analizyraportypodsumowania/documents/raport_koncowy_ ewaluacja_es.pdf (accessed on 30 July 2018).

Sullivan Mort, Gillian, Jay Weerawardena, and Kashonia Carnegie. 2003. Social entrepreneurship: Towards conceptualisation. International Journal of Nonprofit and Voluntary Sector Marketing 8: 76-88. [CrossRef] 
Teo, Albert Chu-Ying, and Wee-Boon Tan. 2013. Developing a Model of Social Entrepreneurship: A Grounded Study Approach. EMES-SOCENT Conference Selected Papers, No. LG13-36. Liege: 4th EMES International Research Conference on Social Enterprise. Available online: https:/emes.net/content/uploads/publications/teo__tan_ ecsp-lg13-36.pdf (accessed on 13 April 2019).

Urbano, David, Nuria Toledano, and Domingo R. Soriano. 2010. Analyzing social entrepreneurship from an institutional perspective: Evidence from Spain. Journal of Social Entrepreneurship 1: 54-69. [CrossRef]

Urbano, David, Elisabeth Ferri, Marta Peris-Ortiz, and Sebastian Aparicio. 2017. Social entrepreneurship and institutional factors: A literature review. International Studies in Entrepreneurship 36: 9-30.

Varga, Eva, and Malcolm Hayday. 2016. A Recipe Book for Social Finance-A Practical Guide on Designing and Implementing Initiatives to Develop Social Finance Instruments and Markets. Luxembourg: European Commission, Directorate-General for Employment, Social Affairs and Inclusion.

Weerawardena, Jey, and Gillian Sullivan Mort. 2006. Investigating social entrepreneurship: A multi-dimensional model. Journal of World Business 41: 21-35. [CrossRef]

Wilkin, Jerzy. 2016. Instytucjonalne i Kulturowe Podstawy Gospodarowania. Humanistyczna Perspektywa Ekonomii. Warszawa: Wydawnictwo Naukowe Scholar.

Wolk, Andrew. 2008. Advancing Social Entrepreneurship: Recommendations for Policy Makers and Government Agencies; Root Cause. Washington: The Aspen Institute. Available online: https://www.aspeninstitute.org/publications/ advancing-social-entrepreneurship-recommendations-policy-makers-government-agencies (accessed on 15 April 2019).

Wronka, Martyna. 2009. Identification of critical success factors of social enterprises-Research results. Management 13: 112-28.

Yin, Robert K. 2009. Case Study Research. Design and Methods, 4th ed. Los Angeles: Sage Publications.

Yin, Robert K. 2015. Studium Przypadku w Badaniach Naukowych. Projektowanie Metody. Kraków: Wydawnictwo Uniwersytetu Jagiellońskiego.

Yitshaki, Ronit, and Fredric Kropp. 2015. Motivations and opportunity recognition of social entrepreneurs. Journal of Small Business Management 54: 546-65. [CrossRef]

(C) 2020 by the author. Licensee MDPI, Basel, Switzerland. This article is an open access article distributed under the terms and conditions of the Creative Commons Attribution (CC BY) license (http://creativecommons.org/licenses/by/4.0/). 